\title{
The Relation Between Physical Activities and the Occurrence of Dysmenorrhea
}

\author{
Adinda Dwi Beauty Fatimah ${ }^{1}$, Fayakun Nur Rohmah ${ }^{{ }^{2}}$ \\ 1 A student of Applied Undergraduate Midwifery Study Program, 'Aisyiyah University \\ Yogyakarta \\ 2 A lecturer of Applied Undergraduate and Professional Midwifery Study Program, Faculty \\ of Health Science, 'Aisyiyah University Yogyakarta \\ *corresponding author, e-mail: fayakun.nurrohmah@unisayogya.ac.id
}

Received: 22/08/2019; published: 29/09/2020

\begin{abstract}
Background: According to a research conducted in Palestine, there are $85.1 \%$ university students reportedly having pain during menstruation. The occurrence of dysmenorrhea in Indonesia is $86 \%$. The high occurrence of dysmenorrhea has less attention from the public and even from the adolescents themselves. One of the factors that influence the occurrence of dysmenorrhea is physical activities. Women who do not do exercise regularly have 3.48 times of risk to experience dysmenorrhea. This study aims to reveal the correlation between physical activities and dysmenorrhea. Method: This was quantitative research with cross sectional design. The population in this study was 136 female students of D4 Medical Laboratory Technology study program. Sixty eight respondents were contributed in this study with exclusion and inclusion criteria. The sampling technique used was total sampling. Bivariate analysis used was the Fisher's Exact correlation test. The research hypothesis was there was a correlation between physical activities and the occurrence of dysmenorrhea. Results: There were 51 respondents who experienced dysmenorrhea $(75 \%)$ and there were 53 respondents who were categorized at moderate physical activities obtained $p<0.05)$. Conclusion: It can be concluded that there is a relation between physical activities and dysmenorrhea
\end{abstract}

Keywords: physical activities; dysmenorrhea; adolescents

Copyright $(2013$ Universitas Ahmad Dahlan. All rights reserved.

\section{Background}

The number of dysmenorrhea cases are considerably high. According to a research conducted in Palestine, there are 846 students out of 956 (85.1\%) having dysmenorrhea (1). Meanwhile, in Indonesia, based on the previous research, the average of students having dysmenorrhea reach $86 \%(2-4)$. 92\% students state that their learning process is disrupted when they are having dysmenorrhea (2). Dysmenorrhea can also cause anxiety in the form of sadness, nervousness, insomnia, irritability and concentration problems affecting on female adolescents' life quality.

The high number of dysmenorrhea cases do not get much attention from the people, even from the young women themselves. A research involving students of Aisyiyah University showed that the students' knowledge about dysmenorrhea was still insufficient. Dysmenorrhea was considered as a common problem. Some of them even hid the pain which was likely to be secondary dysmenorrhea as the consequence of reproductive system diseases. Therefore, female adolescents did not get proper family supports when having dysmenorrhea as they did not openly say what they felt (6). Reproductive health information was needed by all adolescents in university environment including either health professional students or non-health professional students (7). 'Aisyiyah University Yogyakarta (UNISA) through Student-Counseling Information Center (PIK-M), Mahkota Puri, provided a 
reproductive health education service followed by various events giving information of reproductive health for adolescents, especially students of UNISA and society at large. However, the program was hardly used by the students of UNISA.

Physical activities are one of the factors causing dysmenorrhea (4). According to WHO, physical activity is any bodily movement produced by skeletal muscles that requires energy expenditure, including doing sports (8). Physical activities which are like maintaining pressure stability, increasing immune system, maintaining ideal weight, strengthening skeleton and muscles, and improving body flexibility and fitness are physically and biologically beneficial. Moreover, physical activities are mentally useful to reduce stress, to improve confidence, to build sportsmanship, to maintain responsibility, and to build solidarity. Some significant factors affecting physical activities are age, sex, gene, weather, geographic factors, knowledge and perception about healthy life style, motivation, sport, and expectation towards the advantages of physical activities (8).

Physical activity that is generally done by the students is attending lectures. Furthermore, students are obliged to have soft skills which are managerial skill, teamwork, and public communication to support academic skill. Those skills can be obtained through joining an organization activity which is like attending a meeting. Then, apart from attending the theoretical, practical and tutorial classes, some students also join Student Organization (UKM) at UNISA. Related to dysmenorrhea occurrence on the students, 97 students out of $136(71,3 \%)$ had dysmenorrhea and 39 students out of $136(28,7 \%)$ did not have dysmenorrhea in their menstrual period. Some students claimed that dysmenorrhea distracted their teaching and learning process and they often had to leave lectures or organization activities because of it.

Students who do exercise regularly are less likely to have dysmenorrhea $(87,8 \%)$ compared to those who do not have such routine (4). Another study reveals that women who has low physical activities tend to have worse dysmenorrhea (10). A similar study about the relation between physical activity and dysmenorrhea cases has been carried out using Global Physical Activity Questionnaire (GPAQ) instrument (10). In this study, the researcher used Baecke Questionnaire consisting of three indexes that were work index, sports index and leisure-time index in its scoring. Therefore, the writer was interested in conducting a research about the relation between physical activities and dysmenorrhea occurrence.

\section{Method}

This was analytical quantitative research using cross sectional design in which the researcher did the variable measurement at one time. The populations of this research were 136 second semester students majoring D4 Medical Laboratory Technology study program at UNISA. The research inclusion criteria were the respondents who already had menstrual period and the respondents who had normal menstrual cycle. While, the research exclusion criteria (to prevent research bias) were the respondents who had a family dysmenorrhea history, the respondents who were underweight and overweight according to IMT, the respondents who had early menarche, and the respondents who had reproductive disease history, i.e. endometriosis, adenomyosis, and chronic pelvic inflammatory disease. So, there were totally 68 respondents in this research. The sampling technique used was Total Sampling in which the number of samples were the same as the number of the populations so that the number of samples in this research was 68 respondents.

The data collection of physical activity level variable used a research instrument in the form of Baecke Questionnaire that had been translated into Bahasa Indonesia (8) and of dysmenorrhea case variable used yes/ no questions. The data were analyzed using Fisher's Exact Test that was used to find out the relation between variables. The hypothesis of this research was that there was a relation between physical activity level and dysmenorrhea occurrence on the students of D4 Medical Laboratory Technology study program at UNISA.

\section{Results and discussion}

\subsection{Results}

The result revealed in Table 1 shows that 41 respondents out of $68(60.29 \%)$ had a family dysmenorrhea history, that 20 respondents out of $68(29.42 \%)$ had abnormal IMT measurement, and that 7 respondents out of $68(10.29 \%)$ had early menarche. Then, most 
of the respondents were on moderate physical activity (77.9\%) and $75 \%$ of them had dysmenorrhea. The further result is explained in the following table.

Table 1. Frequency Distribution of Respondent Character

\begin{tabular}{lcc}
\hline Variable & \multicolumn{2}{c}{ Total Respondents } \\
\cline { 2 - 3 } & $\mathbf{n}$ & $\%$ \\
\hline Ages & 2 & \\
17 years old & 22 & 2.9 \\
18 years old & 38 & 32.4 \\
19 years old & 6 & 8.9 \\
20 years old & & 8.8 \\
Menstrual Cycles & 10 & 14.7 \\
$\leq 3$ days & 54 & 79.4 \\
4-8 days & 4 & 5.9 \\
$>8$ days & & \\
Menarche & 60 & 88.2 \\
12-14 years & 8 & 11.8 \\
15-17 years & & \\
Physical Activity & 2 & 2.9 \\
Light & 53 & 77.9 \\
Moderate & 13 & 19.1 \\
Heavy & & \\
Dysmenorrhea & 51 & 75 \\
Yes & 17 & 25 \\
No & & \\
\hline
\end{tabular}

Table 2 shows that most respondents who had dysmenorrhea were on moderate physical activity category (84.3\%). It shows that there was a relation between physical activity and dysmenorrhea occurrence $(p$-value $<0,05)$

Table 2. Bivariate Analysis on Physical Activity Level in Relation to Dysmenorrhea Occurrence

\begin{tabular}{lcccccccc}
\hline & \multicolumn{4}{c}{ Dysmenorrhea Cases } & & \multirow{2}{*}{$\mathbf{p}-$} & \\
\cline { 2 - 5 } Physical Activity & $\mathbf{n}$ & $\%$ & $\mathbf{n}$ & \% & & value & PR (95\% Cl) \\
\hline Light & 2 & 3.9 & 0 & 0 & 2 & 0.043 & 5.255 \\
Moderate & 43 & 84.3 & 10 & 58.8 & 53 & & $(1.494-18.477)$ \\
\hline
\end{tabular}

\subsection{Discussion}

The respondents in this research were moslty 19 years old (55.9\%). According to a particular theory, the older the age, the less pain caused by primary dysmenorrhea and the less pain felt by women after childbirth (11). The previous research showed that $63 \%$ women having dysmenorrhea ranged 15-25 years old. The result of the statistical test revealed that there was a relation between ages and dysmenorrhea occurrence, so it could be concluded that ages also affected on primary dysmenorrhea occurrence. The aging process causes deterioration of uterine nerve so that dysmenorrhea occurrence is likely to decrease (12). 54 respondents $(79.4 \%)$ said that their menstrual period lasted $4-8$ days which was normal. The previous research showed that there was a relation between dysmenorrhea occurrence and adolescents' menstrual period cycle. $35 \%$ of the respondents having dysmenorrhea had menstrual period cycle disruptions (oligomenorea), $34 \%$ of them had polimenorea, and $31 \%$ had normal menstrual period cycle. Such conditions showed that there were a number of factors causing dysmenorrhea (13).

Based on the age of menarche, 60 respondents (88.2\%) had menarche at 12-14 years old whic was normal. The previous research showed that $86 \%$ respondents with early menarche ( $<12$ years old) and respondents with menarche at 12-14 years old (56\%) had dysmenorrhea. It also revealed that there was a significant relation between age of menarche and primary dysmenorrhea, so it meant that early menarche could be a factor of primary dysmenorrhea to occur (14). 
Based on the result of the research, most of the respondents were at the moderate physical category $(77.9 \%)$. According to the previous research, $60 \%$ students have sufficient daily physical activities referring to WHO (15) and $75 \%$ respondents have dysmenorrhea. In this research, most respondents $(84 \%)$ who have dysmenorrhea have moderate physical activities. The previous research shows that most of the adolescents (48\%) experienced moderate pain, that $34.6 \%$ experience mild pain and that only $17 \%$ experience severe pain (17.3\%). The pain intensity varies between adolescents because it is affected by their description, perception and experience towards pain. The pain caused by dysmenorrhea can occur due to the increase of prostaglandin production. The higher the production, the stronger contraction occurs in uterus. Meanwhile, most adolescents $(91.8 \%)$ choose non-pharmacological act to deal with dysmenorrhea (16).

$90 \%$ of female adolescents have a problem at their menstrual period and more than $50 \%$ of them have primary dysmenorrhea. Primary dysmenorrhea is menstrual pain that is not related to pathotogical condition in reproductive organs. The risk factors related to dysmenorrhea are age of menarche, family medical history, growth index, eating habit, duration of menstrual bleeding and chemical exposure (16). Dysmenorrhea also occurs because of psychomatic factors causing one has low level of pain tolerance so little pain can even cause discomfort (18).

The result of the study also showed that there was a relation between physical activities and the occurrence of dysmenorrhea. This result was in line with the previous research that there is a negative relation between physical activities and the primary dysmenorrhea degree of pain. It also stats that women who barely do sports are 3.5 times riskier to have primary dysmenorrhea than those who do sports regularly (4). This finding is also supported by another research saying that women who do irregular physical activities are 2.585 times more likely to have dysmenorrhea than those who did regular sports (20).

Heavy physical activities are proven to be able to decrease the intensity of dysmenorrhea on the students of Faculty of Nursing, Padjajaran University, Bandung. The intensity of dysmenorrhea decreases from 4.48 to 1.91 after the students do regular physical activities (11). This result is in line with the previous research that there is a relation between physical activities and the primary dysmenorrhea degree of pain at the first cycle that is negative. The less physical activities done, the more severe pain that is felt (18). Physical activities that are like doing light sports are suggested to deacrease the intensity of dysmenorrhea. Physical activities are one of relaxation techniques to decrease menstrual pain. When doing sports, brain and spinal nerve structure release endorphine, hormone that functios as a natural sedative which makes a person feels good. Moreover, doing regular sports can also increase blood perfusion that is able to decrease either heavy sensation on pelvic or congestive dysmenorrhea. Doing regular sports strongly stimulates the release of Endogenous opioids and beta-Endorphine that can decrease the effect of dysphoric moods and stress and function as non-specific pain relievers $(4,17)$.

Another research mentions that stretching can decrease the intensity of pain. Sport therapy is beneficial to decrease the pain of pirmary dysmenorrhea by decreasing stress, increasing local metabolism, increasing bloodstream to pelvic, increasing the production of enforphine that functions as a natural sedative. Doing sports can decrease the activity of sympathetic nerve handling uterus contraction so the intensity of menstrual pain and its following symptom can also decrease (19). Lack of physical activities can hinder the circulation of blood and oxygen so that the bloodstream and oxygen to uterus are disrupted. That case obstructs the production of endorphine so that can cause stress affecting on the increase of primary dysmenorrhea occurrence (20).

\section{Conclusion}

Based on the result and discussion explained above, it can be concluded that there is a relation between physical activities and dysmenorrhea occurrence. Doing routine physical activities and sports at least 30 minutes a day are also useful to decrease the pain intensity of dysmenorrhea. 


\section{References}

1. Abu Helwa, H.A., Mitaeb, A.A., Al-Hamshri, S., Walled M.S. Prevalence of dysmenorrhea and predictors of its pain intensity among Palestinian female university students. BMC Women's Health. 2018;18(18):1-11.

2. Salsabilla Alifah Putri SA, Yunus M, Fanani E. Hubungan Antara Nyeri Haid (Dismenore) Terhadap Aktivitas Belajar pada Siswi Kelas Xi Sma Negeri 52 Jakarta. The Indonesian Journal of Public Health. 2017;2(2):85-92.

3. Wulandari W, Santi E,Damayanti EAF. Hubungan Antara Tingkat Stres Akademik dengan Kejadian Dismenore Primer Pada Remaja Putri di SMP Darul Hijrah Putri Martapura. Nerspedia. 2018;1(2):123-129.

4. Wati LR, Arifiandi MD, Prastiwi F. Hubungan Aktivitas Fisik dengan Derajat Dysmenorrhea Primer Pada Remaja. Journal of Issues in Midwifery. 2017;1(2):1-18.

5. Zurhayati, Ashar T, Tarigan L. Faktor Predisposing, Enabling, Reinforcing terhadap Kualitas Pengendalian Nyeri pada Remaja mengalami Dismenorea. Jurnal Endurance. 2018;3(2):284-291.

6. Oktavianto E, Kurniati FD, Badi'ah A, Bengu MA, Nyeri dan Kecemasan Berhubungan dengan Kualitas Hidup Remaja Dismenore. Health Science and Pharmacy Journal. 2018:2(1):22-29.

7. Sabilla M, Febrianti T, Efendi R. Analisis Perilaku dan Kebutuhan Informasi Kesehatan Reproduksi Melalui Pusat Informasi Konseling Remaja. Jurnal Kesehatan Indra Husada. 2019;7(1):1-10.

8. Welis W, Rifki MS. Gizi untuk Aktifitas Fisik dan Kebugaran. Padang: Sukabina Press; 2013

9. Lestari DR, Citrawati M, Hardini N. Hubungan Aktivitas Fisik dan Kualitas Tidur Dengan Dismenorea Pada Mahasiswi FK UPN "Veteran" Jakarta. Majalah Kedokteran Andalas. 2018;41(2):48-58.

10. Herdianti KA, Wardana NG, Karmaya INM. Hubungan Antara Kebiasaan Olahraga dengan Dismenore Primer Pada Mahasiswi Pre-Klinik Program Studi Pendidikan Dokter Fakultas Kedokteran Universitas Udayana tahun ajaran 2017. Bali Anatomy Journal (BAJ). 2019;2(1):25-29.

11. Sinaga E, Saribanon N, Sa'adah SN, dkk. Manajemen Kesehatan Menstruasi. Jakarta: Universitas Nasional ;IWWASH;Global One. 2017.

12. Ammar UR. Faktor Risiko Dismenore Primer pada Wanita Usia Subur di Kelurahan Ploso Kecamatan Tambaksari Surabaya. Jurnal Berkala Epidemiolog. 2016;4(1):37-49.

13. Juliana I, Rompas S, Onibala F. Hubungan Dismenore Dengan Gangguan Siklus Haid pada Remaja Di SMA N 1 Manado. Journal Keperawatan. 2019;7(1):1-8.

14. Nurhuda SS, Fathurrahman. Asupan Kalsium dan Magnesium serta Akfititas Fisik Berhubungan dengan Dismenore pada Remaja. Jurnal Riset Pangan dan Gizi. 2019;2(1):12-22.

15. Anindita P, Darwin E, Afriwardi. Hubungan Aktivitas Fisik Harian dengan Gangguan Menstruasi pada Mahasiswa Fakultas Kedokteran Universitas Andalas. Jurnal Kesehatan Andalas. 2016;5(3):522-527.

16. Wulandari A,Hasanah O, Woferst R. Gambaran Kejadian dan Manajemen Dismenore Pada Remaja Putri Di Kecamatan Lima Puluh Kota Pekanbaru. Jurnal Online Mahasiswa FKp. 2018;5(2):468-476.

17. Beddu PS, Mukarramah S, Lestahulu V. Hubungan Status Gizi dan Usia Menarche dengan Dismenore Primer pada Remaja. The Southeast Asian Journal of Midwifery. 2015;1(1):1621.

18. Wati LR, Arifiandi MD, Prastiwi F. Hubungan Aktifitas Fisik dengan Derajat Dysmenorrhea Primer pada Remaja. Journal of Issues in Midwifery. 2017;1(2):1-18.

19. Anisa MV. The Effect Of Exerciseson Primary Dysmenorrhea. Jurnal Majority. 2015;4(2):6065.

20. Mulyati S, Sasnitiari NN. Pengaruh Pola Aktifitas Fisik dan Status Gizi Terhadap Kejadian Dismenore Pada Remaja Putri. Jurnal Riset Kesehatan Poltekkes Depkes Bandung. 2019;11(1):318-325. 